УДК $372.857: 378.1$

DOI:

Леся Височан, кандидат педагогічних наук, дочент кафедри фахових методик і технологій початкової освіти, ДВНЗ "Прикарпатський національний університет імені Василя Стефаника"

\title{
РОЗВИТОК МЕТОДИКИ ВИКЛАДАННЯ ПРИРОДОЗНАВСТВА В ПОЧАТКОВІЙ ШКОЛІ УКРАЇНИ ЗА РАДЯНСЬКОГО ПЕРІОДУ (20-80-ті pp. ХХ ст.)
}

Стаття присвячена актуальній проблемі педагогічної науки - розвитку методики викладання природознавства в початковій школі України за радянського періоду 20-80-х рр. ХХ ст. Визначено три етапи изього процесу та схарактеризовано доробок учених-методистів, які вагомо вплинули на формування науково-теоретичних і організачійно-методичних засад викладання природознавства в початковій школі. Перший етап (20-30-х рр. ХХ ст.) виявився у намаганні надати “утилітарного” спрямування викладанню природознавства, щзо призвело до розчинення ичієї дисичилліни в шкільних програмах з розвитку сільськогосподарської праці. Другий етап (друга половина 40-х рр. - перша половина 60-х рр. ХХ ст.) характерний посиленням уваги до формування природознавчих понять і знань у процесі позакласної роботи та певним “проривом” у розробці науково-методичних засад викладання природознавства у початковій школі завдяки доробку К. Ягодовського, О. Перротте, П. Завітаєва, К. Сонгайло та ін. Третій етап (друга половина 60-x - 80-ті рр. ХХ ст.) позначився подальшим розвитком иієї справи завдяки долучення нової генерації учених-методистів (М. Скаткін, В. Гетьмана, 3. Клепініної, А. Кузнєцова, В. Онищука та ін.) та увінчався генієм В. Сухомлинського.

Ключові слова: радянський період; икільна освіта України; природознавство; методика викладання; початкова икола.

Jim. 11.

Lesya Vysochan, Ph.D.(Pedagogy), Associate Professor of the Professional and Methods and Technologies of Elementary Education Department State Pedagogical University "Vasyl Stefanyk Precarpathian National University"

\section{DEVELOPMENT OF METHODS OFTEACHING NATURAL SCIENCES IN THE PRIMARY SCHOOL OF UKRAINE DURING THE SOVIET PERIOD (20s-80s of the XX century)}

The article is devoted to the topical problem of pedagogical science - the development of methods of teaching science in primary school of Ukraine during the Soviet period of the 20-80's of the twentieth century. Three stages of this process are identified and the achievements of methodological scientists who have had a significant impact on the formation of scientific-theoretical and organizational-methodological foundations of teaching science in primary school are characterized. The first stage of the 20-30's XX century included the second-second half of the 40 's - first half of the 60's of the XX century: the third - second half of the 60's - 80's of the XX century.). The author characterized the works of methodologists who made significant influence on the formation of scientific-theoretical and organizational-methodological foundations of teaching science in primary school. The first stage of the 20-30's of the twentieth century manifested itself in an attempt to give an "utilitarian" direction to the teaching of science, which led to the dissolution of this discipline in school curricula for the development of agricultural labor. The second stage (the second half of the 40's - the first half of the 60's of the twentieth century) was marked by increased attention to the formation of science concepts and knowledge in extracurricular activities and a "breakthrough" in developing scientific and methodological principles of teaching science in primary school thanks to the works of K. Yahodovskiy, O. Perrotte, P. Zavitayeva, K. Sonhaylo and others. The third stage (the second half of the 60's - 80's of the twentieth century) was marked by the further development of this case due to the involvement of a new generation of methodologists (M. Skatkin, V. Hetman, Z. Klepinina, A. Kuznetsov, V. Onyschuk etc.) and was crowned with the genius of $V$. Sukhomlinsky. school.

Keywords: soviet period; a school education of Ukraine; natural sciences; teaching methods; a primary

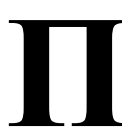

остановка проблеми. Невід'ємним компонентом предметного, всебічного осмислення історико-педагогічних феноменів є 3'ясування їхнього виникнення та етапів становлення і розвитку. 3 таких позицій підходимо до вивчення проблеми розвитку методики викладання природознавства в початковій школі України за радянського періоду 20-80-х рр. ХХ ст. У цей час відбулися складні, суперечливі зрушення і трансформації в цьому процесі: одного боку, були закладені його важливі науково-теоретичні і організаційно-методичні 


\section{РОЗВИТОК МЕТОДИКИ ВИКЛАДАННЯ ПРИРОДОЗНАВСТВА В ПОЧАТКОВІЙ ШКОЛІ УКРАЇНИ ЗА РАДЯНСЬКОГО ПЕРІОДУ (20-80-ті рp. ХХ ст.)}

підвалини, з іншого, він зазнав суцільної ідеологізації та впливу тоталітарної педагогіки. Результати і наслідки цих трансформацій позначаються на розвитку методики викладання природознавства в початкові школі України за сучасних умов. Це актуалізує наукову і практичну значущість цілісного неупередженого осмислення означеної проблеми.

Аналіз останніх досліджень. У вітчизняній педагогічній науці нагромаджено значний доробок з теорії і методики викладання природознавства (Т. Байбара, Н. Бібік, О. Біда, К. Гуз, В. Ільченко, С. Собакар, Н. Коваль, Г. Ковальчук, Л. Нарочна, М. Скаткін та ін.). Окремі аспекти історії викладання природознавства, зокрема в початковій школі за радянського періоду, відображено в історико-педагогічній та методичній літературі (П. Боровицький, М. Верзілін, П. Винниченко, Б. Всесвятский, К. Гончарова, В. Корсунська, Д. Крамаров, В. Кузь, О. Любар, А. Мокрицька Л. Нарочна, Ю. Руденко, З. Сергійчук, М. Стельмахович, В. Танська та ін.). Утім, не було здійснено цілісного осмислення проблеми формування і становлення природничо-наукової підготовки майбутніх учителів початкової школи за доби радянського тоталітаризму.

Мета статті полягає у здійсненні предметного синтезованого аналізу проблеми розвитку методики викладання природознавства в початковій школі України за радянського періоду 20-80-х pp. XX ст. на основі визначення і характеристики основних етапів цього процесу.

Виклад основного матеріалу. За основу реконструкції процесу розвитку методики викладання природознавства в початковій школі України за радянського періоду беремо критерії, які відображають: істотні, якісні зміни у формуванні шкільної системи радянської України; досягнення у розвитку педагогічної i природознавчої наук, які відображають характер формування світоглядної картини світу; вплив радянської ідеологічної машини на означені процеси та ін.

У розвиткуметодики викладання природознавства в початковій школі України за радянського періоду виокремлюємо три основні етапи. Перший припадає на 20-30-ті pp. XX ст. 3 утвердженням більшовицького тоталітарного режиму, Україні була нав'язана радянська, у своїй основі російська, модель розвитку освіти. 3 відновленням i розбудовою мережі різних типів загальноосвітніх шкіл у них уводиться природознавство як один із основних навчальних предметів.

Викладання спершу відбувалося за старими імперськими програмами, адже існувала позиція буцімто їх не варто оновлювати, адже це має відбуватися завдяки творчому підходу самих учителів. На природознавство як навчальну дисципліну стали покладати ідеологічні функції, що відповідали постулатам компартійної ідеології. 3 прийняттям Раднаркомом 21 січня 1918 р. Декрету від про відокремлення школи від церкви перед учительством поставили завдання щодо антирелігійного виховання учнів, тож природознавство, яке грунтувалося на еволюційному вченні, ставало важливим знаряддям для його реалізації [3].

На березневому 1919 р з 'їзді РКП(б) прийняли нову програму компартії. Ї̈̈ важливою складовою стало створення радянської школи, мета якої полягала у вихованні нової генерації, здатної встановити комунізм [3]. Для виконання цієї історичної місії почали поспішно розробляти тимчасові плани і програми для вищих початкових шкіл як перехідного ступеня створення єдиної радянської школи. Це зумовило необхідність перебудови педагогічної освіти в Україні. Після перегляду навчальних програм і планів у педагогічних закладах освіти встановили триместрову систему організації освітнього процесу та запровадили нові дисципліни і методи навчання [3].

Унаслідок наступних численних змін і реформувань (ліквідація університетів, створення спеціальних закладів вищої освіти тощо), в другій половині 20-х рр. ХХ ст. у радянській Україні була створена нова система професійної педагогічної освіти. Вона мала дві основні складові: 1) вищі трирічні педагогічні курси (у 1925 р. перетворені в педагогічні технікуми); 2) інститути народної освіти, що, як правило, мали три факультети, на яких готували працівників соціального виховання, викладачів професійних навчальних закладів, працівників політосвітніх установ [3].

Важливою складовою реформування системи освіти стало створення шкіл першого ступеня і семирічок. В основу їхніх навчальних програм лягли ідеї вивчення трудової діяльності людини та забезпечення зв'язку школи 3 життям i виробництвом. Як наслідок, у початковій школі посилилася увага до природознавства, що активізувало підготовку відповідної навчальнометодичної літератури, приміром, посібника В. Шалаєва “Вивчення живої природи у початковій школі” [10, 3-4] та ін.

Утім, надмірні намагання надати шкільній освіті “утилітарне” спрямування призвели до того, що природознавство як окрема дисципліна фактично розчинилося у складових шкільних програм, якіпередбачалирозвитоксільськогосподарської 
освіти. Природознавство почало виконувати “сервісні” функції, коли для пояснення різних видів сільськогосподарської праці підшукували штучні “біологічні пояснення”. Таке переведення природознавства на “виробничу основу” нівелювало його суть і зміст як окремої навчальної дисципліни.

Запровадження шкільних комплексних програм, що відривали практику від теорії, позначилося на характері розвитку методики викладання природознавства, яке формально отримало статус одного з “провідних предметів“" Учні набували фрагментарних знань, тож школа не забезпечувала належного рівня підготовки для продовження навчання у технікумах і вишах. У цих перетвореннях були і певні позитивні моменти як, приміром, поширення т. зв. дослідного методу. Він передбачав виконання учнем функцій дослідника, який самостійно, на основі власних спостережень і дослідів має досягати “виробничих результатів”. Виникла ситуація, коли вимога обов'язкового використання цього методу визначала зміст природознавства, що змушувало вчителів підбирати відповідний навчальний матеріал [10, 23].

За подолання цих хиб і прогалин виступила група природознавців, які прагнули забезпечити “реальний і дієвий” зв’язок природознавства 3 життям і практикою. Важливим способом розв'язання цього завдання вони вважали запровадження екскурсійно-дослідного методу, який передбачав самостійну роботу учнів 3 вивчення та використання зібраного під час навчальних екскурсій матеріалу. Для реалізації ідеї знані педагоги-натуралісти І. Полянський, В. Наталі та ін. ініціювали створення спеціальних установ т. зв. біостанцій. Вони забезпечували педагогічний супровідпід час перебування дітей уподорожі, зокрема, їхній відпочинок, харчування тощо [2, 13-15].

Лише в 1933 р. природознавство як окремий предмет був уведений до навчального процесу початкової школи. Першочергова увага надавалася розробці його змісту, відповідно до нього визначалися методи викладання. Після чергових змін, за передвоєнних років природознавство почали вивчати лише в 3-4-х класах, а в 1-2-х класах відомості про природу учні отримували на уроках читання і мови. Така ситуація зберігалася до 1945 р. [10, 4-5].

Розвиток науково-методичного забезпечення процесу викладання природознавства у початковій школі в цей час позначився появою низки змістовних видань. Як приклад, відзначимо підручник В. Тетюрьова, що відзначився високим рівнем ілюстрованості, містив завдання для самостійної роботи та методичні рекомендації 3 виготовлення роздаткових матеріалів для проведення уроків [10, 5-6].

Закінчення Другої світової війни, знаменувало початок другого етапу розвитку методики викладання природознавства в початковій школі, що охоплює останні роки панування сталінського тоталітарного режиму і “хрущовську відлигу” (друга половина 40-х - перша половина 60-х рр. ХХ ст.).

Відносно новим явищем стала поява у перші повоєнні роки посібників для організації позакласної роботи з природознавства, зокрема, А. Барбарича (1949), Д. Сергієнка ("Робота гуртків юних натуралістів”, 1947), що зазнав кілька перевидань, М. Скаткіна ("Позакласна робота з природознавства в початковій школі”, 1953), С. Щукіна (“Гуртки юних дослідників”, 1949) та ін. Вони передбачали організацію науково-дослідницької роботи на пришкільних ділянках і в кутках живої природи, проведення літньої практики тощо.

На окреме відзначення заслуговує внесок у розробку науково-методичних засад викладання природознавства вченого-натураліста К. Ягодовського. Його праці “Як викладати природознавство в початковій школі”, “Питання загальної методики природознавства”, “Уроки $з$ природознавства в початковій школі”, “Практичні заняття 3 природознавства в початковій школі" переслідували спільне завдання: як зробити викладання природознавства в 2-4-х класах цікавим, конкретним і наочним. Увага вчителів спрямовувалася на те, щоб учні сприймали об’єкти природи, які вивчаються, “всіма органами чуття”. Задля цього їх слід уважно оглядати, тримати в руках, а за потреби “послухати”, “понюхати” і т. ін. [11, 6].

Педагогічна спадщина К. Ягодовського містить фундаментальні теоретичні та практичні розробки з методики викладання природознавства. Напрацьовані ним підходи до формування природознавчих уявлень і понять в учнів початкової школи базуються на використанні методів спостереження. Приміром, щоб сформувати і дитини образ “берези”, слід починати зі загального спостереження за деревом, відтак здійснюється його детальний розгляд, потім учитель пропонує дітям проблемні запитання, пов'язані з цією рослиною. Учні самостійно формулюють висновки, на їхній основі формуються поняття та розуміння сутності конкретного об'єкта і явища природи. Для оформлення результатів спостереження К. Ягодовський розробив календар природи для кожного з класів початкової школи та методику його ведення [11]. 
За думкою К. Ягодовського, суть методики викладання природознавства полягає у керуванні думками учнів та їхнім розумінням навчального матеріалу. Лише тоді вони здобуватимуть глибокі, усвідомлені, тривкі знання, що є основою формування світогляду $[11,4]$. Спадщина вченогоноватора до сьогодні не втратила науковометодичного значення.

3 думками К. Ягодовського перегукуються підходи вченої-дидакта О. Перротте. Науковометодичні засади вивчення природознавства вона виклала у працях “3 досвіду викладання природознавства у початковій школі”, “Досвід викладання курсу неживої природи у початковій школі”, “Екскурсії з природознавства у початковій школі”, “Досвід роботи з вивчення природи в 3 класі початкової школи" та ін. [4]. Значну увагу О. Перротте приділяла застосуванню наочності. Це виявилося у створених нею ілюстрованих колекціях “Вапняки”, “Сіль”, “Торф” і рекомендацій з їхнього використання.

Ще одним відомим послідовникомК. Ягодовського виступив учений-методист Д. Кайгородов, який у розвитку природознавчої освіти в початковій школі виняткового значення надавав спостереженням у природі Для їхньої організації він розробив спеціальну програму, що містила такий інноваційний компонент, як фенологічні спостереження. Учений стверджував, що любов до природи виникає завдяки зближенню з нею й ніщо так не зближує $з$ природою, як постійне спостереження за нею [9].

До вдосконалення методики проведення уроків із використанням наочних засобів навчання спричинився П. Завітаєв. Він підготував низку посібники для вчителів початкової школи 3 організації і проведення спостережень за предметами та явищами неживої і живої природи. Значну увагу вчений-методист приділив вихованню у дітей любові та бережливого ставлення до навколишнього середовища під час проведення екскурсій.

Третій етап розвитку методики викладання природознавства в початковій школі радянської України припадає на другу половину 60-х - 80-ті рр. $\mathrm{XX}$ ст., коли до цієї справи долучилася нова генерація учених-методистів.

Вагомий внесок у цю справу зробив М. Скаткін, який виступив автором програм і підручників 3 природознавства для 3-4 класів (“Книга для читання з природознавства”, “Нежива природа”, "Природознавство" та ін.). Значну увагу він приділив формуванню мотивації та творчого інтересу до вивчення природознавства, адже “успіх у навчанні багато в чому залежить від того, як учні ставляться до навчальної діяльності. Що більше вони захоплені нею, то продуктивнішою $є$ їхня праця" [5, 3]. Навчальний посібник М. Скаткіна “Методика викладання природознавства в початкових класах" (1959) впродовж двох десятиліть залишався настільною книгою вчителів у плануванні та методиці проведення уроків з природознавства.

Науково-методичні ідеї М. Скаткіна отримали розвиток у працях В. Гетьмана, 3. Клепініної, А. Кузнєцова, В. Онищука, інших ученихметодистів. Зокрема, В. Гетьман у посібнику "Екскурсії з природознавства в 2 і 3 класах" розкрив навчально-виховне значення та методику планування, організації і проведення екскурсій та самостійної роботи учнів, дав поради щодо оформлення, збереження і використання зібраного матеріалу [1].

Заслуговує на відзначення розробка науковометодичних засад підготовки майбутніх учителів початкової школи до викладання природознавства, що здійснювалася у педагогічних училищах та інститутах. У цьому пласті науково-методичної літератури відзначимо праці “Основи природознавства” (В. Горощенко, Л. Мельчаков, I. Степанов, 1978), “Методика викладання природознавства” (В. Горощенко, І. Степанов, 1984), “Методика викладання природознавства у початкових класах" (Ф. Кисельов, 1975) та ін. Автори спиралися на попередній досвід організації викладання природознавства, тож заклали важливі підвалини розробки теорії і практики діяльності у цьому напрямі.

Фундаментальний внесок у ії розвиток зробив В. Сухомлинський у творчості якого значне місце посідають питання спілкуванню дітей з природою. Хрестоматійно відомими став заклик визначного педагога: "Нехай дитина відчує красу й захоплення нею [природною], нехай в її серці і пам'яті назавжди збережуться образи, в яких відтворюється Батьківщина" $[6,38]$.

Свої заняття серед природи В. Сухомлинський називав “уроками мислення”. Завдяки цих ефективних засобів розвитку мовлення та когнітивних здібностей учні отримували можливість самостійно розмірковувати над причинами i наслідками явищ природи, порівнювати якості й ознаки об'єктів навколишнього світу, встановлювати взаємозв'язки у природі. Саму природу В. Сухомлинський розглядав не лише як об'єкт пізнання і сферу активної діяльності вихованців, а й частину їхнього буття та усіх суспільних відносин [7; 8].

Методологічно важливе значення має твердження О. Сухомлинського, згідно з яким 
природа сама собою не виховує, а виховує тільки активна взаємодія дитини з природою. Це стало наріжним принципом організації праці учнів Павлиської середньої школи, в якій освітній процес будувався під гаслом організації такого “повноцінного виховання..., щоб кожен... вихованець за роки навчання в школі перетворив кілька десятків квадратних метрів мертвої глини, мертвого пустиря в родючу землю!"” $[8,549]$.

Висновки і перспективи подальших досліджень. Кожен 3 означених етапів поособливому вплинув на формування науковотеоретичних і організаційно-методичних засад викладання природознавства в початковій школі.

Матеріали представленої статті актуалізують предметне дослідження розвитку методики викладання природознавства в початковій школі за сучасного періоду національного державотворення 1991-2020 pp. у контексті продуктивного використання нагромадженого досвіду за радянського періоду.

\section{ЛІТЕРАТУРА}

1. Гетьман В.Ф. Екскурсії з природознавства в 2 і 3 класах: посібник для вчителів. Київ: Радянська школа, 1975. 103 с.

2. Нарочна Л.К., Ковальчук Г.В., Гончарова К.Д. Методика викладання природознавства. Київ: Вища школа, 1990. 316 с.

3. Ряппо Я. Реформа высшей школы на Украине в годы революции (1920-1924). Харків: Работник просвещения, 1925. 163 с.

4. Перротте А.А. Экскурсии по естествознанию в начальной школе. Москва: Учпедгиз, 1961. 162 с.

5. Скаткин М.Н. Методика преподавания естествознания в начальных классах. Москва: Учпедгиз, 1959. 213 с.

6. Сухомлинский В.А. Сердце отдаю детям. Трилогия издание второе. Киев: Радянська школа, 1987. С.15-234.

7. Сухомлинський О.В. Природа, праця, світогляд. Вибр. тв.: у 5 т. Київ: Радянська школа, 1976. Т. 5. С. 551-562.

8. Сухомлинський В.О. Школа і природа. Вибр. тв.: у 5 т. Київ: Радянська школа, 1976. Т.5. C. 536-551.

9. Танська В.В., Мокрицька А.М. Методика навчання природознавства у початковій школі: навч.-метод. посіб. Житомир: Вид-во ЖДУ ім. І. Франка, 2014. 236 с.
10. Шалаєв В.Ф. Методика викладання природознавства. Київ: Радянська школа, 1949. $244 \mathrm{c}$.

11. Ягодовский К.П. Вопросы общей методики естествознания. Москва: Гос. Уч.-пед. изд. Министерства просвещения РСФСР, 1951. 234

\section{REFERENCES}

1. Hetman, V. F. (1975). Ekskursii z pryrodoznavstva v 2 i 3 klasakh: posibnyk dlia vchyteliv [Excursions in science in the 2nd and 3rd grades: a guide for teachers]. Kyiv, 103 p. [in Ukrainian].

2. Narochna, L. K., Kovalchuk, H.V. \& Honcharova, K. D. (1990). Metodyka vykladannia pryrodoznavstva [Methods of teaching science]. Kyiv, 316 p. [in Ukrainian].

3. Ryappo, Ya. (1925). Reforma vysshey shkoly na Ukraine v gody revolyutsii (1920-1924) [Reform of higher education in Ukraine during the revolution (1920-1924)]. Kharkiv, 163 p.[in Russian].

4. Perrotte, A. A. (1961). Ekskursii po estestvoznaniyu v nachalnoy shkole [Primary School Science Tours]. Moscov, 162 p. [in Russian].

5. Skatkin, M. N. (1959). Metodika prepodavaniya estestvoznaniya $\mathrm{v}$ nachalnykh klassakh [Methodology for teaching natural science in primary grades]. Moscov, 213 p. [in Russian].

6. Sukhomlinskiy, V. A. (1987). Serdtse otdayu detyam [I give my heart to children]. Trilogy, the second edition. Kiev, pp.15-234. [in Russian].

7. Sukhomlynskyi, O. V. (1976). Pryroda, pratsia, svitohliad [Nature, work, worldview]. Selected works: in 5 volumes. Kyiv. Vol. 5. pp. 551-562. [in Ukrainian].

8. Sukhomlynskyi V. O. (1976). Shkola i pryroda [School and nature]. Selected works: in 5 volumes Kyiv. Vol.5. pp. 536-551. [in Ukrainian].

9. Tanska, V.V. \& Mokrytska, A. M. (2014). Metodyka navchannia pryrodoznavstva u pochatkovii shkoli: navch.-metod. posib.[Methods of teaching science in primary school: a textbook]. Zhytomyr, $236 \mathrm{p}$. [in Ukrainian].

10. Shalaiev, V. F. (1949). Metodyka vykladannia pryrodoznavstva [Methods of teaching science]. Kyiv, 244 p. [in Ukrainian].

11. Yagodovskiy, K. P. (1951).Voprosy obshchey metodiki estestvoznaniya [Questions of the general methodology of natural science]. Moscov, 234 p. [in Russian].

Стаття надійшла до редакції 30.10.2020

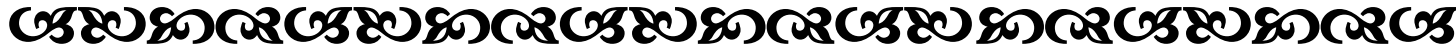

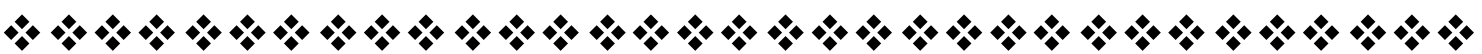

